
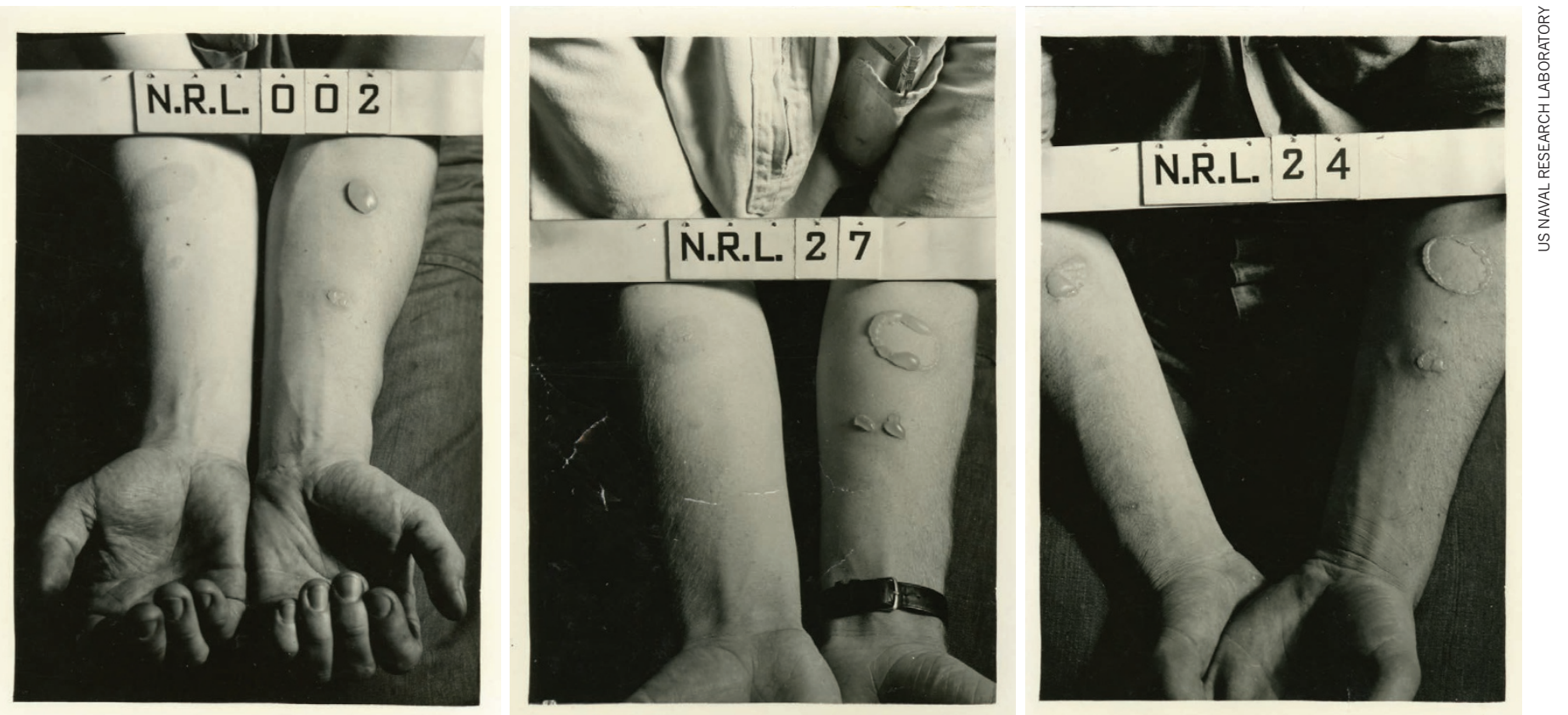

Soldiers' injuries caused by nitrogen mustard and lewisite gas during Second World War experiments at the Naval Research Laboratory in Washington DC.

\title{
CHEMISTRY
}

\section{The hidden war}

\section{Paul A. Lombardo applauds a shocking study detailing the Allies' Second World War experimentation with chemical weapons on their own troops.}

$\mathrm{O}$ ne hundred years ago, soldiers of the First World War were trapped "eye deep in hell", in poet Ezra Pound's words. Mustard gas drifting into the trenches exposed them to the risk of burns, blindness and respiratory damage. Over the course of the war, one million men endured attacks deploying this and other gases; almost 100,000 died. German chemist Fritz Haber devised several weaponized toxic agents used in battle, which some thought more humane than conventional armaments because they could disable soldiers without killing them. Despite winning a Nobel prize for his earlier work in synthesizing ammonia, Haber was shunned by colleagues in later years for his involvement in what was known as the chemists' war.

Gas attacks are strongly associated with that 'war to end all wars'. Yet during and after the Second World War, too, the United States, Canada, Australia and the United Kingdom exposed tens of thousands of soldiers to poison gases for military research. This "unfought chemical war" and its casualties are the subject of historian Susan Smith's Toxic Exposures. Her account, supported by more than ten years of stunningly thorough scholarship, explains how Americans

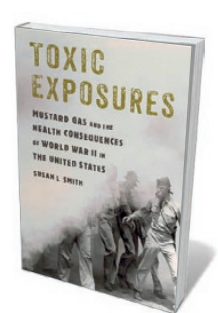

Toxic Exposures: Mustard Gas and the Health

Consequences of World War II in the United States SUSAN L. SMITH Rutgers University Press: 2017. poisoned themselves "in the name of saving lives". She documents how the promise of advancing medical knowledge and promoting national security were enlisted as justification for ignoring human rights.

First, Smith focuses on the intentional exposure of military personnel. Researchers did not seek consent from servicemen for these experiments; instead, officers volunteered their troops. One woman, a service trainee for the US Air Force, reported being ordered to run through a cloud of the organoarsenic compound lewisite in a "gas acquaintance procedure" during flight training in Houston, Texas. In total, researchers recruited at least 60,000 US sailors to study the effects of mustard gas, a toxic agent that incorporates sulfur and chlorine. Other scientists sprayed Canadian soldiers from the air and forced them to march for 3 kilometres, then sit for hours in contaminated clothing. The seriously burned were hospitalized. Military guinea pigs were sworn to secrecy; some withheld information from their doctors for decades, sacrificing their own health.

Investigators speculated that soldiers of different races would respond differently to chemical exposure in terms of pain and injury. At least nine studies attempted to demonstrate varying susceptibility to mustard gas, looking at the "race, pigment and complexion" of soldiers of African American, Puerto Rican and Japanese American origin, as compared to 'whites'. Studies also targeted Native American personnel, such as a soldier in Texas who had mustard gas dripped onto his skin, and was forced to endure exposure to both mustard gas and phosgene in closed chambers without a mask. Physiologist Homer W. Smith of the National Defense Research Committee joined US General Henry Arnold in endorsing the use of chemical warfare against Japanese soldiers in the South Pacific. Said Arnold: "gas, fire, anything to exterminate the entire race".

As Toxic Exposures notes, the racialized nature of this research

\section{DNATURE.COM} For more on science in culture see: nature.com/ booksandarts 
has escaped much scholarly attention. Yet in 1944, a notice in the Journal of the American Medical Association commended 500 men, including 40 soldiers "of Japanese ancestry", who had "voluntarily" been subjected to mustard-gas research. The US research subjects left a segregated society at home to serve in segregated military units. Even the gas masks they tested were sorted for use by race. After the war, reports comparing the penetration of "lethal gases" into the skin of "negro" and "white" research subjects appeared in several professional publications.

Smith also reveals the "toxic legacies of war" in oceans, where the military dumped poisonous munitions in waters off the coasts of Alaska, Hawaii and South Carolina, and in the Gulf of Mexico. There were at least 70 such incidents between 1918 and 1970 . Smith's litany of toxic waste is staggering: some 30,000 tonnes of mustard gas, lewisite and nerve gases such as tabun and sarin; 400,000 chemical-filled bombs, rockets and landmines; 500 tonnes of radioactive waste. Smith suggests that as many as 50 nuclear bombs were "lost at sea". As she writes, some saw the sea as "a convenient sewer".

The book culminates with the story of how wartime toxic exposures led to chemotherapy against cancer. Smith describes a 1943 aerial attack on US ship John Harvey in the harbour of Bari, Italy. The Harvey was storing some 2,000 mustard-gas bombs below decks, intended for retaliation against a possible chemical-warfare offensive; the crew was unaware of the deadly cargo. When German bombs struck, water and air became saturated with mustard gas, exposing hundreds of British and US sailors and around 1,000 Italian civilians. Medical scientists treating the casualties learned that the systemic effects of the gas destroyed victims' white blood cells - fuelling speculation that toxic exposures might help to fight cancer. In the 1940s, compounds related to mustard gas were transformed into therapeutic agents. As early as 1946, US oncologist Cornelius Rhoads applauded these developments as the "peacetime dividends" of chemical warfare.

Smith opens her book with the observation that "war matters to the history of medicine and health matters to the history of war-making”. In 1997, the Chemical Weapons Convention came into force; it is currently signed by 192 countries. Yet it has already been violated many times. Warfare continues, as does military research on chemicals and drugs that could become agents of biowarfare. It is difficult to disagree with the plea that ends Toxic Exposures: public oversight and public debate on this process are needed now more than ever.

Paul A. Lombardo is Regents' Professor of Law at Georgia State University in Atlanta. e-mail:plombardo@gsu.edu

\section{Books in brief}

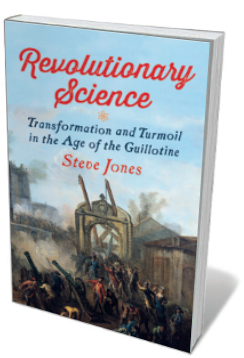

Revolutionary Science: Transformation and Turmoil in the Age of the Guillotine

Steve Jones PEGASUS (2017)

In 1789, as the French Revolution blew the Ancien Régime to smithereens, Paris seethed with scientific geniuses. Many were later guillotined - including the 'father of modern chemistry', Antoine Lavoisier. But, as geneticist Steve Jones reminds us in this sparkling scientific history, they and those who survived (such as astronomer Joseph-Louis Lagrange) laid down a legacy spanning discoveries from the metric system to nitrogenous fertilizer. A fine homage to the evolution of game-changing science, born in the City of Light.

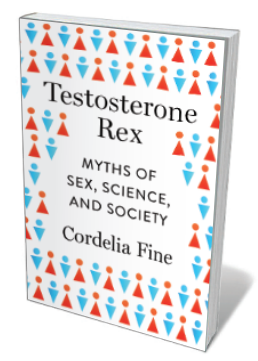

Testosterone Rex: Myths of Sex, Science, and Society

Cordelia Fine W. W. NORTON (2017)

Fed up with men from Mars and women from Venus? In this witty corrective, psychologist Cordelia Fine examines the fraying "biological big picture" of sexual selection, and corrals findings in evolutionary science, neuroscience and endocrinology to add nuance to it. As she demonstrates, the genetic and hormonal components of sex 'collaborate' in complex ways with societal aspects of the developmental system, such as education. Gendered marketing, men-only expert panels and other sexist norms may seem trivial, but their cumulative impact is ultimately damaging.

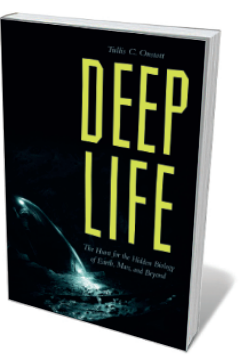

\section{Deep Life}

Tullis C. Onstott PrINCETON UNIVERSITY PRESS (2016)

Few collecting trips can be as claustrophobia-inducing as Tullis Onstott's. The geomicrobiologist's "subterranean safaris" can see him plunging more than 3,000 metres below ground to hunt extremophiles - microbes adapted to extreme conditions, which could offer insight into life on Mars. Onstott's dense account of feats in South African mineshafts and Canadian ice caves is leavened by a vast enthusiasm for the biotic fringe. You're swept along, whether he's describing the "Death-o-Meter" (a gauge of microbial activity) or probing SLiMES (subsurface lithoautotrophic microbial ecosystems).

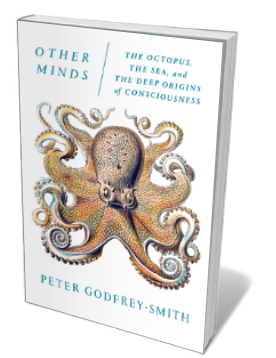

Other Minds: The Octopus, the Sea, and the Deep Origins of Consciousness

Peter Godfrey-Smith FARRAR, STRAUS \& GIROUX (2016)

As a philosopher of science and dedicated scuba diver, Peter Godfrey-Smith is gripped by cephalopods, "an island of mental complexity" in an invertebrate sea. In this insightful study, he weaves their evolutionary history through recent research, his own tales of encounters in the wild and accounts of the idiosyncratic behaviour of lab octopuses, such as drenching visitors in jets of water. From protean bodies to distributed brains, their wondrous otherness leads Godfrey-Smith into fascinating speculations on the alien mind.

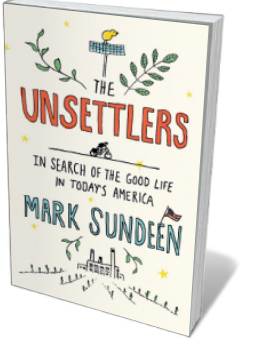

The Unsettlers: In Search of the Good Life in Today's America Mark Sundeen RIVERHEAD (2017)

This deftly written study of experiments in 'ethical living' shows how US utopianism - a blend of fervent idealism and all-American pragmatism - is re-rooting across the country. Mark Sundeen follows three determined couples pursuing extreme sustainability in Missouri, Montana and Michigan. Their expertise in passive solar technology, closed-loop farming, permaculture, ecobuilding and preserving is inspiring. Less so are the hints of self-righteousness a reminder that utopias have a habit of imploding. Barbara Kiser 